\title{
On the issue of harmonization of national tax legislation in integration associations
}

\author{
Oksana Nikolaevna Golovchenko ${ }^{11}$ and Anastasiya Plotskaya ${ }^{2}$ \\ ${ }^{1}$ Financial University affiliated to the Government of the Russian Federation, Department of \\ International and Public Law, Faculty of Law, Moscow, Russia \\ ${ }^{2}$ Campinas State University (UNICAMP), Campinas, Brazil
}

\begin{abstract}
The purpose of the study is a legal analysis of the current supranational tax legislation of the Eurasian Economic Union and European Union integration associations. Special methods of cognition were used in the furtherance of this goal: historical and legal analysis, formal legal method, comparative legal method, the method of legal modeling, the method of interpreting legal norms, which made it possible to identify the existing problems and determine the ways and means of their elimination as well as to determine the differences in approaches in the construction of the European and Eurasian economic integration. Moreover, the methodological basis of the study was formed by general scientific methods of cognition: the dialectical method, which made it possible to reveal the integrity and consistency of legal phenomena; the method of generalization, allowing to draw conclusions as a result of generalization of the data obtained; the comprehensive research method, allowing to consider the theoretical and practical foundations of the process of harmonizing national tax legislation in conjunction. The result of the study was the identification of similar and different concepts for the implementation of supranational policy in the tax systems of the Eurasian Economic Union and European Union countries, aimed at deepening Eurasian and European economic integration, as well as the identification of the trends in the development of harmonization of the national tax legislation of the European Union member states for their subsequent implementation into the tax legislation of the Eurasian Economic Union integration association member countries. The novelty of the study lies in the very formulation of the problem, as well as in the fact that these legal relations incite the states to take actual measures and find new solutions aimed at increasing the country's economic indicators and potential.
\end{abstract}

Keywords: harmonization, tax legislation, integration associations, supranational policy

\section{Introduction}

The complexity and versatility of the integration processes taking place in the world determine the appeal to the advanced experience of European and Eurasian integration,

${ }^{1}$ Corresponding author: ongolovchenko@,fa.ru 
which played the crucial role in the formation of legal regulation for the harmonization of tax legislation in the European Union (EU) and Eurasian Economic Union (EEU) countries. A parallel study of Eurasian and European integrations in the context of a comparative study provides an opportunity to highlight the features of the development of the tax legislation harmonization process and to make a significant contribution to the evolvement of the tax law science, to reduce the degree of negative consequences arising from transformations in the tax sphere, provoking the emergence of legal conflicts and affecting the proper functioning of the tax systems of the EEU member states during the harmonization of national tax legislation, because the successful evolvement of the country directly depends on the ability to influence and affect the integration processes through the use of new opportunities and prospects for the development of legal regulation for the tax legislation harmonization.

Thereby the authors hereof consider it necessary:

1) to study the positive and negative experience of the implementation of the tax legislation harmonization in the EU member states;

2) to identify the most important legal mechanisms and instruments, other ways of reforming national tax systems used by the EU in the implementation of the harmonization of the national legislation of the EU member states, contributing to the strengthening of the single internal market for goods, works, services within the EU, increasing the economic growth of the EU member states, elimination of conditions that impede the implementation of competition at the national level or at the Community level;

3 ) to consider the possibility of implementing legal mechanisms and instruments into the national tax legislation of the EEU member states, which contributed to the creation in the EU of conditions for the formation of a stable, economically attractive and competitive single internal market of the EEU, in order to increase the level of economic development of Russia and the welfare of citizens of the Russian Federation.

Concurrently, in order to achieve the dynamics of Eurasian integration, national tax legislation requires improvement through the harmonization of tax legislation in the EEU member states to resolve existing contradictions, eliminate through the implementation of a coordinated tax policy by the EEU member states barriers and obstacles impeding a well-functioning of the internal market, and improve the national tax legislation of the EEU, ensuring the limitation of the capital flow from one country to another within the framework of the EEU functioning.

Based on the results of the legal analysis of the legislative acts of individual EEU member states in the tax area, problems, expressed in the lack of uniformity of legal regulation of tax legal relations, which are an obstacle to building an efficiently developing internal market, appear evident. Harmonization of tax legislation [1], as a tool for Eurasian integration, should contribute to the achievement of the proper level of legal regulation of national tax legislation, timely respond by legal means to dynamically developing public relations in the rapidly developing internal market of integration associations of foreign countries. However, the effectiveness of the implementation of the process of harmonization of tax legislation, in our opinion, directly depends on the effectiveness of the interaction of the competent authorities of the EEU member states in the tax area and tax administration.

The abovementioned complex of problems unequivocally requires a search for solutions. The need to identify measures aimed at improving the current national tax legislation in the context of a protracted economic crisis against the background of sanctions restrictions will contribute to reduction of pressure on consumers and increase in purchasing power, which will bring closer to one of the main goals of Eurasian integration - increasing the welfare of citizens of the EEU member states. However, in order to find solutions, it is necessary to analyze the features of building European and Eurasian 
integration, which will make it possible to assess and formulate the prospects for the development and deepening of economic integration within the EEU.

\section{Methods}

To solve the goals and objectives set herein, special methods of cognition, such as historical and legal analysis, formal legal, comparative legal, the method of legal modeling, the method of interpreting legal norms, enabling the identification of the existing problems and determination of the ways and means of their elimination were used to define the differences in approaches to the construction of European and Eurasian economic integration.

At the same time, the methodological basis of the research is formed by general scientific methods of cognition: the dialectical method, which made it possible to reveal the integrity and consistency of legal phenomena; the method of generalization, allowing to draw conclusions as a result of generalization of the data obtained; a comprehensive research method that allows considering the theoretical and practical foundations of the process of harmonizing national tax legislation in conjunction.

\section{$3 \quad$ Results}

The study made it possible to formulate a number of conclusions confirming the relevance of the topic under consideration and to assume the unlimitedness of the considered issues arising in the framework of economic integration.

1. A careful tax policy pursued by the EEU member states slows down the process of Eurasian integration, which prevents the creation and implementation of effective tools for the development of national tax systems through the harmonization of national tax legislation.

2. The process of harmonization of national tax legislation is an integral instrument of economic integration, the deepening of which also determines the level of economic development of each individual region.

3. The emerging needs and their resolution predetermine the emergence of new needs. For example, in financial and information resources for reforming national tax systems, which, in turn, also requires a joint solution at the level of an integration association.

4. The need to change the principles of legal regulation of the process of harmonization of national tax legislation and the transition from declarative to mandatory nature of the relevant legal relationship.

5. The constantly emerging need for legal analysis of the current tax legislation of foreign countries and the identification of effective tools for economic integration should be reflected in the implementation of national tax policy.

\section{Discussion}

The target orientation of integration makes it possible to determine the depth of economic integration through the harmonization of national tax legislation $[2,3]$. That is why the results of Eurasian and European integration are different. Thus, harmonization in the EU contributed to the introduction of significant changes in national tax legislation [4]. In 1993, after the entry of the Treaty on the EU into force [5], the member states agreed on the directions of deepening economic integration through the harmonization of VAT and excise taxes, although in most countries (Great Britain, Greece, Italy, etc.) there was no such tax as VAT [6], this contributed to the reform of tax systems, providing for a transitional period 
for the introduction of new types of taxes and the elimination of conflicts in national tax legislation [7].

Since any legal relationship associated with making changes to national tax systems is not easy to implement, in this regard, one can observe different opinions in foreign literature on the need to harmonize national tax legislation and deepen economic integration [8-10]. However, the figures confirming the level of economic development of each individual state prove the effectiveness of the measures taken by the states within the framework of the implementation of a single economic policy [11].

The goals of building Eurasian integration [12] are of a different nature. Initially, it is necessary to determine that after the collapse of the USSR [13], the former Soviet republics identified the possibility of integration in the future, providing that when building tax systems, the state will include certain types of taxes, such as: VAT, excise taxes, taxes on income and profits [14], which are reflected in the present time period. At the same time, tax systems are different in their content, reflecting the peculiarities of the development of each region separately. Therefore, although the process of Eurasian integration is being carried out much more slowly compared to the EU, the EEU member states were initially aimed at integration. However, within the framework of the Eurasian economic integration, the states are not ready to lose their tax sovereignty and are aimed at independence in the implementation of appropriate reforms in tax legislation, realizing joint intentions, but independently.

At the same time, within the framework of the EEU, even minor changes are met with misunderstanding on the part of taxpayers, which prompts the states to carry out gradual reforms, providing for subsequent integration (for example, a system for tracking goods, switching to submitting VAT reports in electronic format, introducing mandatory provisions on CCP, etc.). Due to the cautious tax policy pursued by the EEU member states, conflicts in the national tax legislation do not arise. Moreover, the codification of national tax legislation allowed the states to systematize tax legal relations, to introduce additional institutions of tax law into tax systems, which, of course, is a positive stimulus for the development of the economy of the EEU member states.

The lack of unified approaches to the implementation of tax policy by the EEU countries and the emerging collisions with the supply of goods to the EEU internal market require a detailed study. The study of the positive experience of reforming the tax systems of the EU countries makes it possible to determine the most favorable instruments for the implementation of tax policy in national tax legislation, to effectively administer tax revenues to the budgets of the EEU member states.

\section{Conclusion}

Thus, the legal analysis of the features of the formation of integration processes within the EU and the EEU made it possible to formulate a number of conclusions and proposals aimed at eliminating existing legal conflicts and improving the supranational tax legislation of the EEU integration association, contributing to the development of the theory of tax law and the practice of its application. Unequivocally, the identification of the features of the formation of legal regulation of the harmonization of national tax legislation is preceded by the constant work of supranational institutions aimed at deepening integration processes, since the increase in the economic indicators of the EEU member states depends on the effectiveness of the phenomenon under consideration [15].

\section{References}


1. O.N. Golovchenko, Finan. Law 1, $42-44$ (2016)

2. C.Bailey, German Hist. 28(4), 456 (2002)

3. Treaty establishing the European Coal and Steel Community, ECSC Treaty. Accessed on: June 26, 2021. [Online]. Available:

http://europa.eu/legislation_summaries/institutional_affairs/treaties/treaties_ecsc_en.ht $\mathrm{m} /$

4. Offic. J. Europ. Communit. L(169), 1 (1987)

5. Offic. J. Europ. Communit. C(191), 104 (1992)

6. E. Christian, M. Weidenbaum, The Allure of Value-Added Taxes: Examining the Pros and Cons (Washington University, 1989)

7. G. Winckler (ed.), Tax Harmonization and Financial Liberalization in Europe (Palgrave Macmillan, 1992)

8. W. Kerber, Jahrbuch für Neue Polit. Ökon. 17, 199 (1998)

9. P. Mooslechner, Competition - Location - Harmonization: The Challenges of Capital Taxation after EU Enlargement, in Capital Taxation after EU Enlargement. Proceedings of OeNB Workshops, 6, 13 (2005)

10. H. Sinn, Europ. Econ. Rev. 34, 489 (1990)

11. VAT refunds and reimbursements: A quantitative and qualitative study Assessment of national legislation determining the conditions for repayment of excess VAT

TAXUD/2017/DE/328 FWC No. TAXUD/2015/CC/131. Accessed on: June 26, 2021. [Online]. Available:

https://ec.europa.eu/taxation_customs/sites/taxation/files/vat-refunds-legislative-report. pdf

12. Treaty on the Eurasian Economic Union (Astana, 29.05.2014). Accessed on: June 26, 2021. [Online]. Available:

http://www.consultant.ru/document/cons_doc_LAW_163855/

13. O.N. Golovchenko, Fin. Law 3, 23-28 (2015)

14. The Commonwealth. Inform. Bul. Council of Heads of State and the Council of Heads of Govern. of the CIS, 3, 15-13 (1992)

15. Statistics of foreign and mutual trade in goods within the EEU. Accessed on: June 26, 2021. [Online]. Available:

http://www.eurasiancommission.org/ru/act/integr_i_makroec/dep_stat/tradestat/Pages/d efault.aspx 